Crime, Histoire \& Sociétés / Crime, History \& Societies

Vol. 9, $n^{\circ} 2 \mid 2005$

Varia

\title{
Eric Monkkonen (1942-2005)
}

\section{Randolph Roth}

\section{(2) OpenEdition}

\section{Journals}

Electronic version

URL: https://journals.openedition.org/chs/349

DOI: $10.4000 /$ chs.349

ISSN: 1663-4837

\section{Publisher}

Librairie Droz

\section{Printed version}

Date of publication: 1 December 2005

Number of pages: 157-158

ISBN: 978-2-600-01054-2

ISSN: 1422-0857

\section{Electronic reference}

Randolph Roth, "Eric Monkkonen (1942-2005)", Crime, Histoire \& Sociétés / Crime, History \& Societies [Online], Vol. 9, n² | 2005, Online since 11 February 2009, connection on 23 March 2022. URL: http:// journals.openedition.org/chs/349; DOI: https://doi.org/10.4000/chs.349

This text was automatically generated on 23 March 2022

(C) Droz 


\section{Eric Monkkonen (1942-2005)}

\section{Randolph Roth}

1 Eric Monkkonen, who passed away on May 30, 2005 at the age of 62, was one of the greatest historians ever to write on the history of crime. An urban and social science historian by training, he dedicated his life to understanding the social problems that, like many historians of his generation, he believed most pressing: poverty, prejudice, and violence. He was an iconoclast in his approach to those problems, on good terms with ideologues of all stripes but unwilling to settle for ideological answers. He wanted proof, and he was always willing to put his own beliefs to the test and to change them if they proved wrong. That, he thought, was the best way to learn humility: watching a cherished theory go up in flames. He preferred, of course, to right his own wrongs by rethinking his early work-that way, he said, he got twice the publications and still looked good. But he was willing (and indeed eager) to be revised by other scholars, which is why he shared his data even before he had finished analyzing them. He wanted to know how others looked at them, and if they ended up understanding them better than he did, that was fine with him. That was the way to progress, and Eric was a firm believer in progress, intellectual, moral, and substantive. His optimism was infectious, and he gave his students and colleagues reason to be optimistic, by contributing mightily to the advance of our knowledge of the modern world.

2 Eric spoke often of his commitment to empiricism and pragmatism. Gathering data and finding patterns were his passions. As he told me once, we social science historians are the great explorers of our age, seeing things that no human has ever seen, because we have been privileged to have the tools, the friends, and the institutional support to do so. He was always ahead of the curve when it came to computers, the web, statistics, and social theory. He was impatient with premature history, as he made clear in his 1986 essay in the American Historical Review on «The Dangers of Synthesis» He did not think it a priority to sum up our knowledge of the past, since there was so much that had to be learned before we could do that responsibly. That said, he did write a history of urban America!

3 Perhaps his most important finding as a historian of crime was that homicide rates are changeable and often counter-intuitive. He marveled at the fact that the homicide rate 
dropped precipitously in New York City in the late nineteenth century, when every social theory suggests it should have gone out of control. In such a diverse, mobile, anonymous, uprooted society, murder should have been common, especially during the depression of the 1890s, the second worst in U. S. history. Understanding why sudden drops in homicide rates occurred could give us the ability to lower homicide rates permanently, something he wanted to see happen the world over.

Eric grew up in Duluth, Minnesota, and received all of his degrees, including a Ph.D. in history, from the University of Minnesota. He taught first at the University of North Carolina-Charlotte and then at the University of California at Los Angeles, where he was a professor of history and policy studies. Eric was the author of many distinguished books on urban history and the history of crime, including The Dangerous Class: Crime and Poverty in Columbus, Ohio (1975), Police in Urban America (1981), America Becomes Urban (1986), Urban Police in the United States (1996), and Murder in New York City (2000). At the time of his death he was working on a comparative history of homicide in Los Angeles, New York, and other cities. Thanks to his son, Paavo, and his former student, Petula Iu, the data for Eric's Los Angeles project, 1830-2003, are available in preliminary form through the History Violence Database (http://www.sociology.ohio-state.edu/cjrc/ hvd).

\section{AUTHOR}

\section{RANDOLPH ROTH}

(Ohio State University, Columbus) 